\title{
Electrophoretic Characterization of Anti-platelet Aggregating Proteins/Peptides from Salivary Gland of Rhipicephalus (Boophilus) microplus
}

\author{
Surbhi $^{1 *}$, Nirmal Sangwan ${ }^{1}$, Arun K. Sangwan ${ }^{2}$, Vijender Singh ${ }^{1}$ and Ankit Kumar ${ }^{3}$ \\ ${ }^{1}$ Department of Veterinary Physiology and Biochemistry, ${ }^{2}$ Department of Veterinary \\ Parasitology, College of Veterinary Sciences, ${ }^{3}$ RVDEC, Lala Lajpat Rai University of \\ Veterinary and Animal Sciences, Uchani, Karnal, Haryana, India \\ *Corresponding author
}

\begin{tabular}{l} 
K e y w or d s \\
$\begin{array}{l}\text { Anti-platelet } \\
\text { platelet adhesion, } \\
\text { Rhipicephalus } \\
\text { (Boophilus) } \\
\text { microplus, Salivary } \\
\text { gland, Thrombin }\end{array}$ \\
\hline $\begin{array}{l}\text { Article Info } \\
\text { Accepted: } \\
\text { 20 June } 2018 \\
\text { Available Online: } \\
\text { 10 July } 2018\end{array}$ \\
\hline
\end{tabular}

\section{Introduction}

Ticks are economically devastating obligate hematophagous ectoparasites that infest mammals, birds, reptiles and amphibians. These are classified into two major families, one is Ixodidae also called as hard ticks, other is Argasidae also called as soft ticks and third
Ticks are economically devastating arthropod ectoparasites of livestock that exclusively feed on host blood. Ticks saliva is a crucial weapon against host-defense systems. Several small fragmented attempts are made by researchers to characterize these biomolecules. Being extremely small in size and quantity, numerous such molecules escape the deep insight of biochemists employing routine gel electrophoresis followed by Coomasie brilliant blue (CBB) staining. In a systematic manner, the present study aimed to isolate and electrophoretically characterize the salivary gland anti-platelet aggregating proteins/peptides from Rhipicephalus (Boophilus) microplus ticks. Salivary glands dissected out from female ticks were homogenized and fractionated into 120 fractions using gel filtration chromatography. All fractions were screened for anti-thrombotic activity. Nine fractions which inhibit thrombin induced platelet aggregation were electrophoretically characterized with SDS-PAGE followed by silver staining of gel. Amongst all 9 fractions which showed antiplatelet aggregating activity, protein band of approximate $64.1 \mathrm{kDa}$ was found predominant indicating towards peptide/protein with thrombin induced platelet aggregation inhibitory activity. Experiment was repeated many folds to evaluate the presence of the $64.1 \mathrm{kDa}$ bands in active fractions. Subsequently, the potential biomolecule identified need further purification and characterization to explore its therapeutic and immunization potential.

A B S T R A C T 
(boophilus) microplus species is endemic in India infesting dairy animals. These ticks transmit pathogens like Babesia, Anaplasma etc. to cause diseases bovine babesiosis and anaplasmosis. The control of tick infestation mainly depends on the use of chemical acaricides which are easily available and indiscriminately used all over India (Sharma et al., 2012). The global economic losses by tick infestation through direct production losses and the associated cost of treatment has been estimated at US\$14,000-18,000 million loss annually; while in India tick-borne diseases in livestock alone accounts for US\$498.7 million loss per annum (Minjauw and McLeod, 2003).

During evolutionary development, bloodfeeding arthropods have evolved antihaemostatic mechanisms to counteract their host immune system. However, the cocktail of anti-haemostatic compounds in tick saliva differs between species (Kazimírová and Štibrániová, 2013). Thrombin plays acentral role in hemostasis, it cleaves specific peptide bonds in fibrinogen to form fibrin, induces platelet aggregation. Thrombin mainly acts through two receptors present on platelet membrane, namely, platelet activating receptors- 1 and platelet activating receptors- 4 (Ofosu, 2003; Huntigton, 2005). Research into the mechanisms by which ticks inhibit host haemostasis has led to the discovery and characterization of a variety of compounds with diverse biological activities and potential use in development of novel pharmaceuticals (Kazimírová, 2007; Francischetti et al., 2009; Koh and Kini, 2009; Chmelar et al., 2012). In addition to discovery of new drug candidates, studies on tick anti-haemostatics contribute to our understanding of the host parasite interactions (Kazimírová and Štibrániová, 2013). So keeping in view above facts the present study was aimed to characterize the proteins/peptides present in salivary gland of Rhipicephalus (Boophilus) microplus.

\section{Materials and Methods}

\section{Collection of ticks}

Adult female ticks of $R$. (B.) microplus were collected from villages around Hisar district of Haryana.

\section{Tick dissection and collection of tick salivary glands}

Adult female of $R$. microplus ticks were washed with normal saline and immobilized individually on a petri dish using glue with their dorsal surface upward. Using fine scalpel blade and fine tip forceps, ticks were incised along the dorsal-lateral margin, and the dorsal integuments were removed under a stereoscopic dissection microscope. Then the salivary glands were removed by the method of Wu et al., (2010). A total number of one hundred pairs of salivary glands from $R$. microplus female ticks were collected in HEPES Saline buffer, $\mathrm{pH} 7.0$ and stored in liquid nitrogen at -196 degree Celsius till further analysis.

\section{Extract preparation}

Salivary glands (one hundred pairs) were homogenized under ice using tissue homogenizer (T10 basic ULTRA-TURRAX) in HEPES saline buffer, $\mathrm{pH}$ 7.0. The homogenate was centrifuged at $12000 \mathrm{X} \mathrm{g}$ for $7 \mathrm{~min}$ at $4^{\circ} \mathrm{C}$. The supernatant was further filtered through Millex-GV sterile syringe filter having, $25 \mathrm{~mm}$ PVDF and $.22 \mu \mathrm{m}$ vent. Then the supernatant was diluted to $2 \mathrm{ml}$ with $50 \mathrm{mM}$ Tris-Cl, pH 8.3, which was then fractionated by gel filtration chromatography.

\section{Fractionation and isolation of proteins/peptides}

The fresh salivary gland extract $(500 \mu 1)$ from $R$. microplus ticks were applied to Sephacryl 
S-200 gel filtration column $(1 \mathrm{~cm} \times 60 \mathrm{~cm})$ equilibrated with $50 \mathrm{mM}$ Tris-HCL, $\mathrm{pH} 7.5$ with $100 \mathrm{mM} \mathrm{KCL}$. Elution was performed with $40 \mathrm{mM}$ Tris- $\mathrm{HCl}, \mathrm{pH} 7.5$ and fractions were collected each of $1.5 \mathrm{ml}$. The molecular mass determination of unknown peptides in the fractions was done by comparing the $\mathrm{V}_{\mathrm{e}} / \mathrm{V}_{\mathrm{o}}$ for the protein in question to the $\mathrm{V}_{\mathrm{e}} / \mathrm{V}_{\mathrm{o}}$ of protein standards of known molecular mass (Cytochrome c from horse heart $12.4 \mathrm{kDa}$ sigma C7150, Carbonic anhydrase from bovine erythrocytes $29 \mathrm{kDa}$ sigma C7025, Albumin from bovine serum $66 \mathrm{kDa}$ sigma A8531, alcohol dehydrogenase $150 \mathrm{kDa}$ sigma A8656, $\beta$-Amylase from sweet potato $200 \mathrm{kDa}$ sigma $\mathrm{A} 8781)\left[\mathrm{V}_{\mathrm{e}}\right.$ was elution volume and $\mathrm{V}_{\mathrm{o}}$ was void volume]. The $\mathrm{V}_{\mathrm{o}}$ of the column was the volume of effluent required for the elution of Blue dextran (molecular mass of $~ 2,000$ $\mathrm{kDa}$, sigma-D4772).

\section{Estimation of total protein in fractions}

The protein concentrations in fractions were estimated by the method of Bradford (1976)at $595 \mathrm{~nm}$ using ELISA reader using BSA as standard.

\section{Isolation of bovine platelets}

Blood sample was collected from jugular vein of buffalo calves maintained by the Department of Veterinary Physiology and Biochemistry at LUVAS animal farm in vials containing $0.1 \mathrm{M}$ trisodium citrate as anticoagulant in the ratio of 9:1. Samples collected were centrifuged at $1000 \mathrm{rpm}$ to get the platelet rich plasma (PRP). The PRP was removed in another centrifuge tube and was centrifuged at $4000 \mathrm{rpm}$ to get the platelet pellet. Supernatant was discarded and pellet was washed two times with tyrode buffer ' $A$ '. Finally the pellets having the platelets was reconstituted with tyrode buffer ' $\mathrm{B}$ ' so that the final concentration of platelets was $2 \times 10^{8} / \mathrm{ml}$ and OD of 0.15 at $650 \mathrm{~nm}$.
Platelet aggregation assay of fractions having proteins/peptides

To estimate the effects of proteins/peptides present in isolated fractions on platelet aggregation, the method followed by Francischetti et al., (2000) with little modification was used. Platelets in each well were incubated with antagonist Gly-Pro-ArgPro amide $(1 \mathrm{mM})$ and salivary glandfractions having proteins/peptides for $10 \mathrm{~min}$ at 37 ${ }^{\circ} \mathrm{C}$.Then aggregation was initiated by thrombin $(0.5 \mathrm{nM})$. The absorbance was noted at $650 \mathrm{~nm}$ at every $5 \mathrm{~min}$ interval for 20 mintues.

\section{Electrophorectic separation and characterization of anti-platelet aggregating proteins/peptides}

Proteins/peptides in fresh crude salivary extracts as well as in fractions having antiplatelet aggregating activities were electrophoretically separated by using $12 \%$ discontinuous SDS-PAGE (Hames, 1998) on vertical gel apparatus (Bio-Rad MiniPROTEAN). Gels were stained by silver staining (Morrissey, 1981) and the approximate molecular weight of various proteins/peptide bands were calculated with reference to the standard marker proteins using gel documentation system.

\section{Results and Discussion}

A total of 120 fractions of salivary gland extract of Rhipicephalus (boophilus) microplus ticks were collected. These 120 fractions were further tested for platelet aggregation inhibitory activity by using thrombin as agonist and Gly-Pro-Arg-Pro amide as antagonist and found that only 9 fractions showed platelet aggregation inhibitory activities. Platelets have a central role in hemostasis. Thrombin is a key enzyme that catalyses conversion of fibrinogen into fibrin clot, activates blood coagulation factors 
and blood platelet reactions. So in order to counteract the host hemostatic mechanism blood-sucking invertebrates have evolved various mechanisms that interfere with blood coagulation of their hosts (Markwardt, 1994; Arocha-Piñango et al., 1999). Hirudin, a single chain peptide of 65 residues, was isolated from the leech Hirudo medicinalis and is currently the most potent natural direct inhibitor of thrombin (Salzet, 2001). A number of distinct platelet aggregation inhibitors have been described in various blood-sucking insects such as Rhodnius prolixus, Ixodes scapularis, Ornithodoros moubata etc.

\section{C1 C2 F22F23 F25 F27 F31}

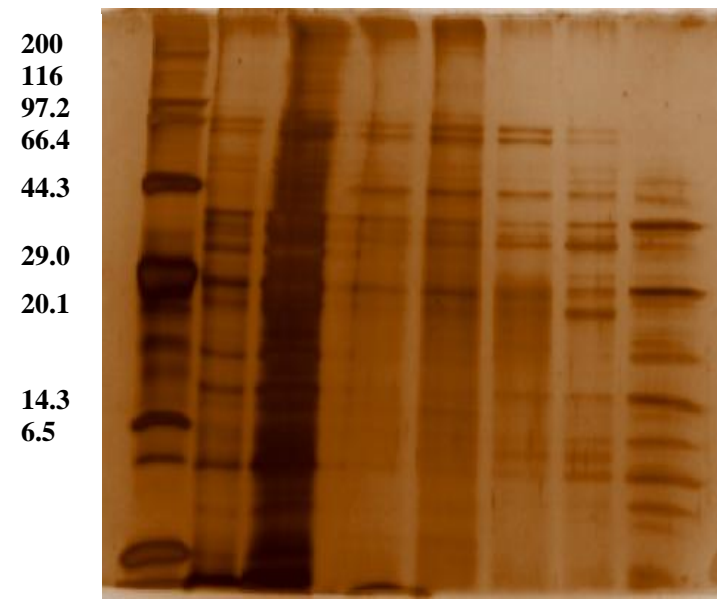

Figure.1 Electrophoretic protein profiling of fractions of Rhipicephalus (Boophilus) microplusin12\%SDS PAGE stained with silver staining.Track-M,bands of molecular weight marker;track-C1,diluted crude SGE of Rhipicephalus (Boophilus) microplus;tracl-C2, crude SGE of Rhipicephalus (Boophilus) microplus track-F22,fraction22;track-F23, fraction23;trackF25, fraction25;track-F27,fraction27; track-F31,fraction31.

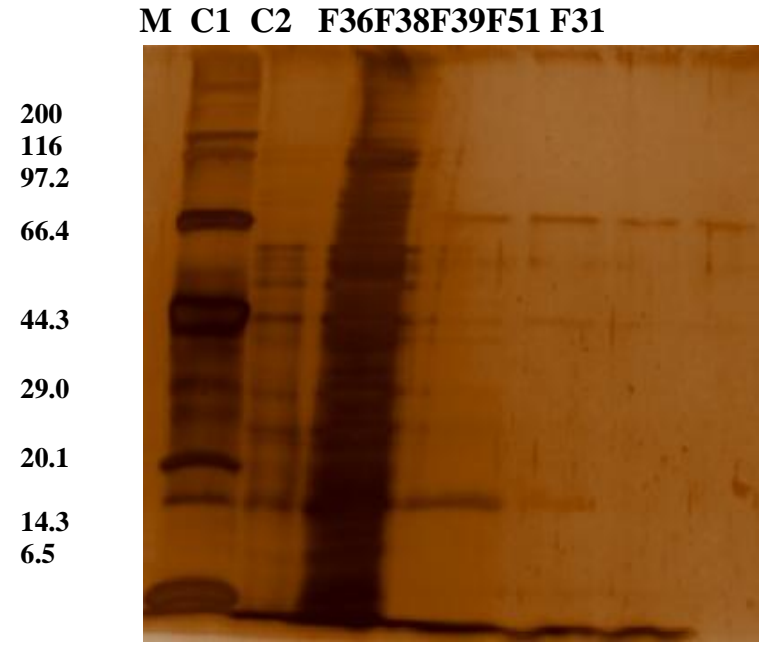

Figure.2 Electrophoretic protein profiling of fractions of Rhipicephalus (Boophilus) microplus in12\%SDS PAGE.Track-M,bands of molecular weight marker;track-C1, diluted crude SGE of Rhipicephalus (Boophilus) microplus;tracl-C2, crude SGE of Rhipicephalus (Boophilus) microplus track-F36, fractio36;track-F38, fraction38;trackF39, fraction39;track F51, fraction51. The gel was stained with Silver staining. 
Table.1 Approximate molecular weight (kDa) of the protein bands of Rhipicephalus (Boophilus) microplus salivary gland protein fractions.

\begin{tabular}{|c|c|c|c|c|c|c|c|c|c|c|c|}
\hline \multicolumn{12}{|c|}{ Mol. Wt. (KDa) } \\
\hline S.No. & Marker & Crude & $\begin{array}{c}\text { Fraction } \\
22\end{array}$ & 23 & 25 & 27 & 31 & 36 & 38 & 39 & 51 \\
\hline 1 & 200 & - & - & - & - & - & - & - & - & - & - \\
\hline 2 & - & $\begin{array}{l}174.5 \\
132.9\end{array}$ & - & - & - & - & - & - & - & - & - \\
\hline 3 & 116 & - & - & - & - & - & - & - & - & - & - \\
\hline 4 & - & 106.1 & - & - & - & - & - & 98.3 & - & - & - \\
\hline 5 & 97.2 & - & - & - & - & - & - & - & - & - & - \\
\hline 6 & - & $\begin{array}{l}92.1, \\
81.1, \\
74.3, \\
70.5,\end{array}$ & $\begin{array}{l}94.6, \\
88.5, \\
74.3, \\
69.5\end{array}$ & $\begin{array}{l}92.7, \\
87.3, \\
73.8, \\
68.6\end{array}$ & $\begin{array}{c}91.5 \\
86.1\end{array}$ & $\begin{array}{l}91.5, \\
85.6, \\
72.4, \\
67.2\end{array}$ & & 92.4 & - & - & - \\
\hline 7 & 66.4 & 65.4 & 64.5 & 63.9 & 63.3 & 63.3 & 66.8 & 66.4 & 66.0 & 65.2 & 64.1 \\
\hline 8 & - & $\begin{array}{l}58.0 \\
53.3, \\
45.5\end{array}$ & $\begin{array}{l}57.2 \\
52.6 \\
49.3\end{array}$ & $\begin{array}{l}56.4, \\
51.8\end{array}$ & $\begin{array}{l}56.1, \\
51.4\end{array}$ & $\begin{array}{l}55.9, \\
51.1, \\
44.9\end{array}$ & $\begin{array}{l}62.2, \\
55.6, \\
51.1, \\
44.7\end{array}$ & $\begin{array}{l}57.5, \\
53.7 \\
48.8\end{array}$ & - & - & - \\
\hline 9 & 44.3 & - & - & - & - & - & - & - & - & - & - \\
\hline 10 & - & $\begin{array}{l}41.3, \\
37.7 \\
35.9 \\
32.1 \\
30.4\end{array}$ & $\begin{array}{l}43.1 \\
40.9 \\
31.9 \\
30.3\end{array}$ & $\begin{array}{l}42.7, \\
40.5, \\
36.9, \\
31.5, \\
29.9\end{array}$ & $\begin{array}{l}42.4 \\
40.3, \\
31.3\end{array}$ & $\begin{array}{l}42.8, \\
40.1, \\
31.1\end{array}$ & $\begin{array}{l}42.7, \\
41.3, \\
37.5, \\
36.5, \\
30.8\end{array}$ & $\begin{array}{l}40.7 \\
36.9\end{array}$ & 40.4 & - & - \\
\hline 11 & 29 & - & - & - & - & - & - & - & - & - & - \\
\hline 12 & - & 21.4 & - & 25.3 & 21.0 & $\begin{array}{l}23.7, \\
20.3\end{array}$ & 23.4 & $\begin{array}{l}28.0 \\
23.6\end{array}$ & - & - & - \\
\hline 13 & 20.1 & - & - & - & - & - & - & - & - & - & - \\
\hline 14 & - & $\begin{array}{l}19.6 \\
16.7\end{array}$ & 19.5 & $\begin{array}{l}19.9, \\
14.6\end{array}$ & & 18.8 & $\begin{array}{l}18.5 \\
16.5, \\
15.3\end{array}$ & 18.0 & 17.9 & - & - \\
\hline 15 & 14.3 & - & - & - & - & - & - & - & - & - & - \\
\hline 16 & - & 9.9 & - & - & - & - & - & - & - & - & - \\
\hline 17 & 6.5 & - & - & - & - & - & - & - & - & - & - \\
\hline
\end{tabular}

These molecules include direct collagen inhibitors, inhibitors of platelet adhesion to collagen (Karczewski et al., 1995), apyrases and catechol oxidases. In addition to thrombin inhibitor, NO-releasing molecules, fibrinogen-receptor antagonists and specific 
inhibitors of collagen-induced platelet aggregation (Noeske-Jungblut et al., 1994; Keller et al., 1993) have also been reported. Analyses of anti-platelet aggregating proteins/peptides may be useful tools in cell biology and may also have potential for therapeutic applications.

Further, electrophoretic characterization of proteins/peptides present in these 9 fractions showing platelet aggregating inhibitory activities were done. The protein bands in all the 9 fractions ranged from $9.9 \mathrm{kDa}$ to 174.5 $\mathrm{kDa}$. Out of these 9 fractions, some of the fractions i.e. fraction no. 22, 23, 25, 27, 31, 36, 38 and 39 (Figure 1 and 2) were found to have multiple protein bands of different molecular weight (Table 1) while only single protein band of approximate molecular weight $64.1 \mathrm{kDa}$ was found in fraction no. 51 (Figure 2).

This single protein might be responsible for inhibition of thrombin induced platelet aggregation in Rhipicephalus (Boophilus) microplus. Similarly Wang et al., (1996) also reported a novel inhibitor of human platelet aggregation, named variabilin, from salivary glands of the hard tick Dermacentor variabilis with a mass of 4985.5 daltons. Similarly in Bothrops jararaca, a glycoprotein with molecular weight of $61 \mathrm{kDa}$ was reported by De Morais et al., (2009). The Boophilus microplus anticoagulant Protein' (BmAP), with 60,000 Da, blocked thrombin active site (Horn et al., 2000), while microphilin, with $1,770 \mathrm{Da}$, interacted with thrombin exosite I (Ciprandi et al., 2006). BmGTI isolated from gut of Boophilus microplus, molecular weight is estimated to be in the range of $26 \mathrm{kDa}$, this protein was different from BmAP and microphilin, two Boophilus microplus salivary anticoagulants (Ricci et al., 2007). Novel antithrombin molecules was identified from the ixodidae tick, Haemaphysalis longicornis madanin 1 and 2, were 7-kDa proteins (Iwanaga et al., 2003). A 30-kDa salivary allergen from Aedes (aegyptin) was also reported, which were shown to specifically block collagen-induced human platelet aggregation (Calvo et al., 2007). So the protein/peptide found in fraction no. 51 in the present study could be exploited further to purify it. The mechanism of action how these peptides are inhibiting platelet aggregation still need to be studied. Theses proteins/peptides can be used either in therapeutics or as a source of antigen for the development of vaccine.

Out of total of 120 fractions collected, only 9 salivary fractions of Rhipicephalus (boophilus) microplus ticks showed thrombin induced platelet aggregation inhibition. On electrophorectic characterization by SDSPAGE of these 9 fractions, some of the fractions were found to have multiple protein bands of different molecular weight while only single protein band of approximate molecular weight $64.1 \mathrm{kDa}$ was found in fraction no. 51. So these promising antiplatelet aggregating proteins present in fraction no. 51 could be further purified and exploited for its mechanism of action of inhibition of platelet aggregation which can be further usedfor therapeutic purposes as well as for raising anti-tick vaccine.

\section{References}

Arocha-Piñango, C.L., Marchi, R., Carvajal, Z. and Guerrero, B. 1999. Invertebrate compounds acting on the hemostatic mechanism. Fibrinolysis. 10: 43-68.

Bradford, M. M.(1976). A Rapid and Sensitive Method for the Quantitation of Microgram Quantities of Protein Utilizing the Principle of Protein-Dye Binding.Anal.Biochem.72: 248-254.

Calvo, E., Tokumasu, F., Marinotti, O., Villeval, J. L., Ribeiro, J. M. and 
Francischetti I. M. (2007). Aegyptin,a novel mosquito salivary gland protein, specifically binds to collagen and prevents its interaction with platelet glycoprotein VI, integrin alpha2beta1, and von Willebrand factor. $J$ Biol Chem. 282 (37): 26928-38.

Chmelar, J., Calvo, E., Pedra, J. H. F., Francischetti, I. M. B. and Kotsyfakis, M. (2012). Tick salivary secretion as a source of antihemostatics. $J$. Proteomics. 75: 3842-3854.

Ciprandi, A., De Oliveira, S. K., Masuda, A., Horn, F. and Termignoni, C. (2006).Boophilus microplus: its saliva contains microphilin, a small thrombin inhibitor. Exp. Parasitol. 114 (1): 4046.

De Morais, K. B., Vieira, C. O., Hirata, I. Y. and Tanaka-Azevedo, A. M. (2009). Bothropsjararaca antithrombin: isolation, characterization and comparison with other animal antithrombins. Comp. Biochem. Physiol. 152 (2): 171-176.

Francischetti, I. M., Ribeiro, J. M, Champagne, D. and Andersen, J. (2000).Purification, cloning, expression, and mechanism of action of a novel platelet aggregation inhibitor from the salivary gland of the bloodsucking bug, Rhodniusprolixus.J. Biol.Chem. 275: 12639-12650.

Francischetti, I. M., Sá-Nunes, A., Mans, B. J., Santos, I. M. and Ribeiro, J. M. C. (2009). The role of saliva in tick feeding.Front. Biosci.14: 2051-2088.

Hames, B.D. (1998). Gel Electrophoresis of Proteins A Practical Approach, Third Edition, Oxford University Press.

Horn, F., Coutinho dos Santos, P. and Termignoni, C. (2000). Boophilus microplus anticoagulant protein: an antithrombin inhibitor isolated from the cattle tick saliva. Arch. Biochem.
Biophys.384: 68-73.

Huntigton, J.A. (2005). Molecular recognition mechanisms of thrombin.J. Thromb. Haemost.3: 1861-1872.

Iwanaga, S., Okada, M., Isawa, H., Morita, A., Yuda, M. and Chinzei, Y. (2003). Identification and characterization of novel salivary thrombin inhibitors from the ixodidae tick, Haemaphysalislongicornis. Eur. J. Biochem. 270(9) : 1926-34.

Karczewski, J., Waxman, L., Endris, R. G. and Connolly, T. M. (1995). An inhibitor from the argasid tick Ornithodorosmoubata of cell adhesion to collagen. Biochem.Biophys. Res. Comm. 208(2): 532-541.

Kazimírová, M. (2007)."Bioactive compounds in ticks acting on host thrombo hemostasis, 'In Thrombohemostatic Disease Research, Fifth edition, Nova Science Publishers, New York.Pp: 95-113.

Kazimírová, M. andŠtibrániová, I. (2013). Tick salivary compounds: their role in modulation of host defences and pathogen transmission. Front. Cell. Infect. Microbiol. 20(3): 43.

Keller, P. M., Waxman, L., Arnold, B. A., Schultz, L. D., Condra, C. and Connolly, T. M. (1993) .Cloning of the cDNA and expression of moubatin, an inhibitor of platelet aggregation. J. Biol. Chem. 268: 5450-5456.

Koh, C. Y. and Kini, R. M. (2009).Molecular diversity of anticoagulants from haematophagous animals. Thromb. Haemost.102: 437-453.

Markwardt, F. (1994).Coagulation inhibitors from animals feeding on blood. RevistaI beroamericana de Trombosis y Hemostasia.7: 225-231.

Minjauw, L. and McLeod, A. (2003).Tick borne diseases and poverty. The impact of tick and tick borne diseases on the 
livelihoods of small-scale and marginal livestock owners in India and eastern and southern Africa. DFID animal health programme. UK: Centre for Tropical Veterinary Medicine, University of Edinburgh, UK. 124.

Morrissey, J.H. (1981). Silver stain for proteins in polyacrylamide gels: a modified procedure with enhanced uniform sensitivity. Anal.biochem. 117(2):307-310.

Noeske-Jungblut, C., Kratzschmar, J., Haendler, B., Alagon, A., Possani, L., Verhallen, P., Donner, P. and Schleuning, W. (1994). An inhibitor of collagen-induced platelet aggregation from the saliva of Triatomapalli dipennis. J. Biol. Chem. 269 (7): 5050-5053.

Ofosu, F. A. (2003). Protease activated receptors 1 and 4 govern the responses of human platelets to thrombin. Tranfus. Apheresis. Sci. 28: 265-268.

Ricci, C. G., Pinto, A. F., Berger, M. and Termignoni, C. (2007). A thrombin inhibitor from the gut of Boophilus microplus ticks. Exp. Appl. Acarol.
42: 291-300.

Salzet, M. (2001). Anticoagulants and inhibitors of platelet aggregation derived from leeches. FEBS.Lett.492: 187-192.

Sharma, A. K., Kumar, R., Kumar, S., Nagar, G., Singh, N. K., Rawat, S. S., Dhakadd, M. L., Rawat, A. K. S., Ray, D. D. and Ghosh, S. (2012). Deltamethrin and cypermethrin resistance status of Rhipicephalus (Boophilus) microplus collected from six agroclimatic regions of India. Vet. Parasitol.188: 337-345.

Wang, X., Coons, L. B., Taylor, D. B., Stevens, S. E. Jr.and Gartner, T. K. (1996).Variabilin, a novel RGDcontaining antagonist of glycoprotein IIb-IIIa and platelet aggregation inhibitor from the hard tick Dermacentor variabilis. J. Biol. Chem.271(30): 17785-90.

Wu, J; Wang, Y; Liu, H; Yang, H; Ma, D; Li, J; Li, D; Lai, R and Yu, H (2010) Two immunoregulatory peptides with antioxidant activity from tick salivary glands. J. Biol. Chem. 285: 1-19.

\section{How to cite this article:}

Surbhi, Nirmal Sangwan, Arun K. Sangwan, Vijender Singhand Ankit Kumar. 2018. Electrophoretic Characterization of Anti-platelet Aggregating Proteins/Peptides from Salivary Gland of Rhipicephalus (Boophilus) microplus Int.J.Curr.Microbiol.App.Sci. 7(07): 2619-2626. doi: https://doi.org/10.20546/ijcmas.2018.707.307 